\title{
Transcriptome analysis of Bifidobacterium longum strains that show a differential response to hydrogen peroxide stress
}

\author{
Taylor S. Oberg ${ }^{\mathrm{a}, *}$, Robert E. Ward ${ }^{\mathrm{a}}$, James L. Steele ${ }^{\mathrm{b}}$, Jeff R. Broadbent ${ }^{\mathrm{a}}$ \\ a Department of Nutrition, Dietetics and Food Sciences, Utah State University, 8700 Old Main Hill, Logan, UT 84322-8700, USA \\ ${ }^{\mathrm{b}}$ Department of Food Science, University of Wisconsin, 1605 Linden Drive, Madison, WI 53706-1565, USA
}

\section{A R T I C L E I N F O}

\section{Article history:}

Received 17 January 2015

Received in revised form 16 June 2015

Accepted 19 June 2015

Available online 21 August 2015

\section{Keywords:}

Bifidobacterium longum

Probiotics

Oxidative stress

\begin{abstract}
A B S T R A C T
Consumer and commercial interest in foods containing probiotic bifidobacteria is increasing. However, because bifidobacteria are anaerobic, oxidative stress can diminish cell viability during production and storage of bioactive foods. We previously found Bifidobacterium longum strain NCC2705 had significantly greater intrinsic and inducible resistance to hydrogen peroxide $\left(\mathrm{H}_{2} \mathrm{O}_{2}\right)$ than strain D2957. Here, we explored the basis for these differences by examining the transcriptional responses of both strains to sub-lethal $\mathrm{H}_{2} \mathrm{O}_{2}$ exposure for 5- or 60 -min. Strain NCC2705 had 288 genes that were differentially expressed after the 5-min treatment and 114 differentially expressed genes after the 60 -min treatment. In contrast, strain D2957 had only 21 and 90 differentially expressed genes after the 5- and 60-min treatments, respectively. Both strains showed up-regulation of genes coding enzymes implicated in oxidative stress resistance, such as thioredoxin, thioredoxin reductase, peroxiredoxin, ferredoxin, glutaredoxin, and anaerobic ribonucleotide reductase, but induction levels were typically highest in NCC2705. Compared to D2957, NCC2705 also had more up-regulated genes involved in transcriptional regulation and more down-regulated genes involved in sugar transport and metabolism. These results provide a greater understanding of the molecular basis for oxidative stress resistance in B. longum and the factors that contribute to strain-to-strain variability in survival in bioactive food products.
\end{abstract}

(c) 2015 Elsevier B.V. All rights reserved.

\section{Introduction}

Consumption of food or food ingredients with bioactive properties has increased in recent years and probiotic bacteria represent one of the most promising categories of bioactive food ingredients. The term probiotic refers to living microorganisms which, when ingested at sufficient numbers, exert a beneficial effect on the host organism beyond inherent general nutrition (Fontana et al., 2013). Currently, bacteria from the genera Lactobacillus and Bifidobacterium are the most widely used probiotic bacteria added to functional foods. Bifidobacteria are Gram-positive, non-acid-fast, non-spore forming, non-motile, anaerobic, catalase negative rods of irregular shape, with a G + C content of $55-67 \%$, and are part of the normal gastrointestinal flora in human adults (Klaassens et al., 2009; Vaughan et al., 2005). Bifidobacteria are thought to promote or provide several health related functions, including a decrease in severity of the side effects associated with antibiotics use, a reduced incidence of infection in patients receiving irradiation therapy,

\footnotetext{
* Corresponding author. Fax: +1 4357972379.

E-mail address: taylor.oberg@aggiemail.usu.edu (T.S. Oberg).
}

a decrease in the duration of diarrhea due to various etiologies, improved lactose digestion, a reduced frequency of allergic reactions, normalization of blood lipid composition, and a decrease in gut transit time (Chen et al., 2010; Dong et al., 2010; Zhang et al., 2009; Stanton et al., 2001; Bermudez-Brito et al., 2012). Although no conclusive data is available on a minimal effective dose of probiotics in humans, results from several clinical trials suggest a direct dose-effect correlation (Waller et al., 2011; Meance et al., 2001; Reid et al., 2001). In practice this means that bifidobacteria need to be delivered at very high concentrations in bioactive foods to function as a probiotic. At present, yogurt or fermented milks are the most common vehicle foods for delivery of probiotic bifidobacteria, but cheese, ice cream, infant formula, fruit juice, and other foods are also used to a lesser extent (Makinen et al., 2012). One of the major hurdles to production and storage of bioactive foods containing bifidobacteria as a probiotic is oxidative stress. This is because bifidobacteria are anaerobic and lack common enzymes such as superoxide dismutase that detoxify oxidative free radicals in the presence of oxygen (Vries and Stouthamer, 1969; Barrangou et al., 2009; Ruiz et al., 2011; Oberg et al., 2011). We previously found Bifidobacterium longum strain NCC2705 had greater intrinsic and inducible resistance to $\mathrm{H}_{2} \mathrm{O}_{2}$ than strain D2957. Specifically, 60 min 
Table 1

Target genes oligonucleotide primers for RT-PCR.

\begin{tabular}{|c|c|c|c|c|}
\hline \multirow[t]{2}{*}{ Protein function (Gene ID) } & \multicolumn{2}{|l|}{ Primer sequence $\left(5^{\prime}-3^{\prime}\right)$} & \multirow[t]{2}{*}{ Amplicon size (bp) } & \multirow[t]{2}{*}{ Annealing temp $\left({ }^{\circ} \mathrm{C}\right)$} \\
\hline & Forward & Reverse & & \\
\hline Peroxiredoxin (BL0615) & GTGGCTGAGCGTGGCGACTT & ACCTGGTCGCCGTGCTCGTA & 146 & 61.5 \\
\hline Glutaredoxin (BL0668) & CACCAAGCGCCAGCTCACCA & GCGTGATGACCACCGGAGCC & 122 & 61.5 \\
\hline Thioredoxin (RBLN00690) (BLD_0988) & GCGCGTTCGGCCCGATTTTC & GGGCCAGATCCTGGTTGGCG & 99 & 61.5 \\
\hline Ferredoxin (BL01563) & TACGAGGGTTCCCGCTCGCT & AAGATGGCCTCGGTGGGGCA & 89 & 61.5 \\
\hline Ferridoxin (BL1725) & GGCTACGCGGGTGCATTGGT & CCGGGGTGAAACGTGGGTCG & 105 & 61.5 \\
\hline Anaerobic Ribonuclease reductase (BL1752) & TCAAGGGGCGTTACACCGGC & GGCGCGAGCCACATCGTACA & 97 & 61.5 \\
\hline DnaK (BL0520) & CCCAGCGTCAGGCCACCAAG & GCTGCGGTCGGCTCGTTGAT & 79 & 61.5 \\
\hline
\end{tabular}

exposure to sublethal concentration ( $1.25 \mathrm{mM}$ ) of $\mathrm{H}_{2} \mathrm{O}_{2}$ was shown to significantly improve survival $(P<0.05)$ of $B$. longum NCC2705 at lethal $(5.25 \mathrm{mM}) \mathrm{H}_{2} \mathrm{O}_{2}$ concentrations, but a similar response was not detected with strain D2957 (Oberg et al., 2011). Additionally, B. longum NCC2705 showed a 1.5 -fold higher intrinsic $\mathrm{H}_{2} \mathrm{O}_{2}$ resistance than D2957 (Oberg et al., 2011). The purpose of this study was to explore the physiological basis for these differences by determining the transcriptional responses of B. longum NCC2705 and D2957 to sublethal $\mathrm{H}_{2} \mathrm{O}_{2}$ exposure.

\section{Materials and methods}

\subsection{Media, strains and culture conditions}

Bacterial strains were maintained as glycerol freezer stocks at $-80^{\circ} \mathrm{C}$, and working cultures were prepared by two successive transfers ( $1 \%$ innoculum, vol/vol) into peptonized milk medium (MP5; Oberg et al., 2011) with anaerobic incubation at $37^{\circ} \mathrm{C}$ for $18 \mathrm{~h}$. Batch cultures of each strain were prepared by dilution of the working culture to an absorbance at $600 \mathrm{~nm}\left(\mathrm{~A}_{600}\right)$ of 1.0 in MP5 medium, then inoculated at $1 \%(\mathrm{vol} / \mathrm{vol})$ into $1 \mathrm{~L}$ of MP5 in a New Brunswick BioFlo III fermenter (New Brunswik Scientific, Edison, New Jersey). Cells were incubated at $37^{\circ} \mathrm{C}$ with an agitation rate of $100 \mathrm{rpm}$ to prevent sedimentation. A gas mixture of $5 \% \mathrm{CO}_{2}$ and $95 \% \mathrm{~N}_{2}$ was continuously passed over the headspace of the fermenter to achieve anaerobic conditions, and the $\mathrm{pH}$ was maintained at 6.5 by automatic addition of $15 \%(\mathrm{vol} / \mathrm{vol}) \mathrm{NH}_{4} \mathrm{OH}$. Bifidobacteria were incubated until the cells reached early stationary-phase (approximately $12 \mathrm{~h}$ ) (Oberg et al., 2011).

\subsection{RNA isolation}

RNA isolation was performed as previously described (Oberg et al., 2013). Cells were grown in batch culture under pH control to early stationary phase and then samples $(5 \mathrm{~mL})$ were harvested by centrifugation at $7500 \times g$ for $10 \mathrm{~min}$. The cell pellets were suspended in $50 \mathrm{~mL}$ of pre-warmed MP5 media containing a sublethal $\mathrm{H}_{2} \mathrm{O}_{2}$ concentration of $1.25 \mathrm{mM}(16)$ for 5 (T1) or 60 (T2) min. Immediately after treatment, $100 \mathrm{~mL}$ of RNAprotect bacterial reagent (Qiagen, Inc., Valencia, CA) was added to the cell suspensions to stop transcription and prevent mRNA degradation. A control sample was also prepared which was not exposed to $\mathrm{H}_{2} \mathrm{O}_{2}$. Cells in RNA protect were held at room temperature for $10 \mathrm{~min}$, then collected by centrifugation at $9500 \times \mathrm{g}$ for $10 \mathrm{~min}$ and stored at $-20^{\circ} \mathrm{C}$ until RNA isolation.

Cell pellets were thawed at room temperature and suspended in $900 \mu \mathrm{L}$ of a lysis solution containing $20 \mathrm{mg}$ lysozyme (Sigma-Aldrich) and $20 \mathrm{U}$ of mutanolysin (Sigma-Aldrich) per $\mathrm{mL}$ in $1 \mathrm{mM}$ TE buffer adjusted to $\mathrm{pH}$ 7.6. Samples were incubated for $30 \mathrm{~min}$ at $37^{\circ} \mathrm{C}$ on a shaker incubator at $240 \mathrm{rpm}$, after which $20 \mu \mathrm{L}$ of proteinase $\mathrm{K}$ (Omega Bio-Tek Inc., Norcross, GA) (>600 mAU/ml) was added and the samples were returned to the shaker/incubator for $30 \mathrm{~min}$. The RNA was then isolated using the Aurum total
RNA mini kit (Biorad, Hurcules, CA) following the vendor's recommended procedures. The quantity of recovered RNA was measured with a NanoDrop 8000 spectrophotometer (ThermoFisher Scientific, Waltham, MA) and the quality of the RNA was assayed using an Agilent 2100 bioanalyzer (Agilent Technologies, Inc., Waldbronn, Germany). Samples that had sufficient quantities ( $>10 \mu \mathrm{g}$ ) of quality RNA were stored at $-80^{\circ} \mathrm{C}$ until needed.

\subsection{Synthesis and labeling of $c D N A$}

cDNA synthesis and labeling was performed as described previously (Oberg et al., 2013). cDNA was synthesized and labeled as recommended by the Affymetrix (Santa Clara, CA) protocol for prokaryotic target preparation in the GeneChip Expression Analysis Technical Manual (media.affymetrix.com). The cDNA was fragmented into approximately $50-100$ bp using DNAse I and labeled with GeneChip DNA labeling reagent (Affymetrix, Santa Clara, CA) and terminal deoxynucleotidyl transferase (Promega, Madison, WI). Fragmentation labeling efficiency was measured by gel shift assay.

\subsection{DNA microarrays hybridization and statistical analysis}

DNA microarray hybridization and statistical analysis was performed as described previously (Oberg et al., 2013). Sample hybridization was performed at the Center for Integrated Biosystems at Utah State University against a custom Affymetrix bifidobacterial DNA microarray designed to include 3113 shared and unique chromosomal genes predicted to occur in B. longum NCC2705 and D2957. The only predicted coding sequences not included in the microarray design were redundant transposases and rRNA genes. Hybridization was performed according to the Affymetrix protocol for prokaryotic target hybridization in the GeneChip expression analysis technical manual using a hybridization temperature of $50^{\circ} \mathrm{C}$. The DNA microarrays were scanned using the HP GeneArray scanner (Affymetrix, Santa Clara, CA) to generate raw intensity values for each probe.

Statistical analysis of microarray data was performed using Bioconductor (www.bioconductor.org) in the open source statistical platform $\mathrm{R}$ (www.r-project.org). The raw probe data was preprocessed using the RMA-MS method (Stevens et al., 2008) and filtered to only include genes that had a high signal intensity and a low coefficient of variation. To test for differential expression, the preprocessed, filtered data was analyzed using the limma/eBayes method (Scholtens and von Heydebreck, 2005). Genes were determined to be significantly differentially expressed if they had a false discovery rate corrected $P$-value $<0.05$. The significantly differentially expressed genes were grouped according to function and by treatment times and strain. 


\section{Metabolism \\ Energy production and conversion Carbohydrate transport and metabolism Amino acid transport and metabolism Nucleotide transport and metabolism Coenzyme metabolism \\ Information storage and processing Translation and ribosomal structure Transcription \\ DNA replication and recombination \\ Cellular processes \\ Protein turnover and stress response \\ Cell secretion \\ Ion transport \\ Cell envelope biogenesis \\ Cell division and chromosome partitioning \\ Poorly characterized/ \\ General function \\ Uncharacterized/ \\ Hypothetical proteins}

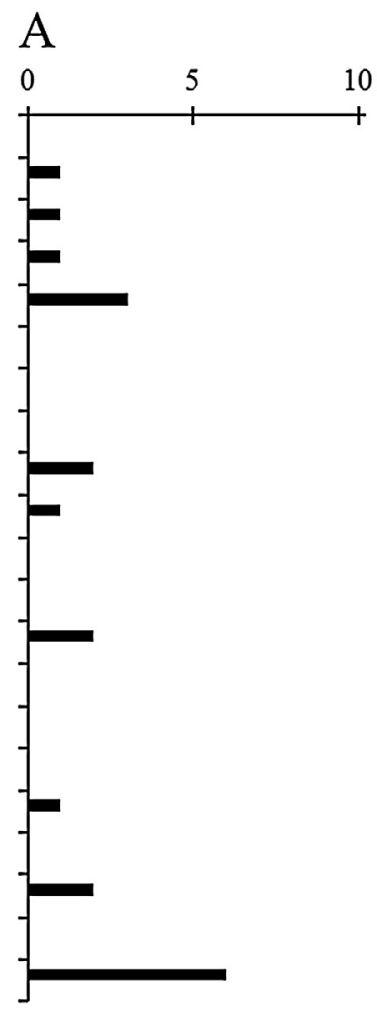

\section{$\mathrm{B}$}

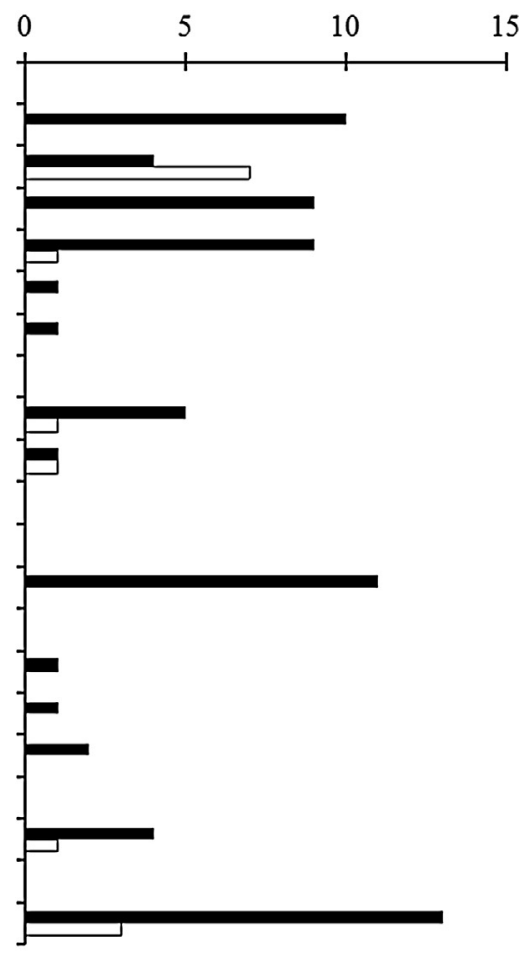

Fig. 1. Numbers of B. longum D2957 genes, grouped according to functional category, that were significantly upregulated (black bars) or downregulated (white bars) after $1.25 \mathrm{mM} \mathrm{H}_{2} \mathrm{O}_{2}$ exposure for $5 \mathrm{~min}$ (panel A) or $60 \mathrm{~min}$ (panel B).

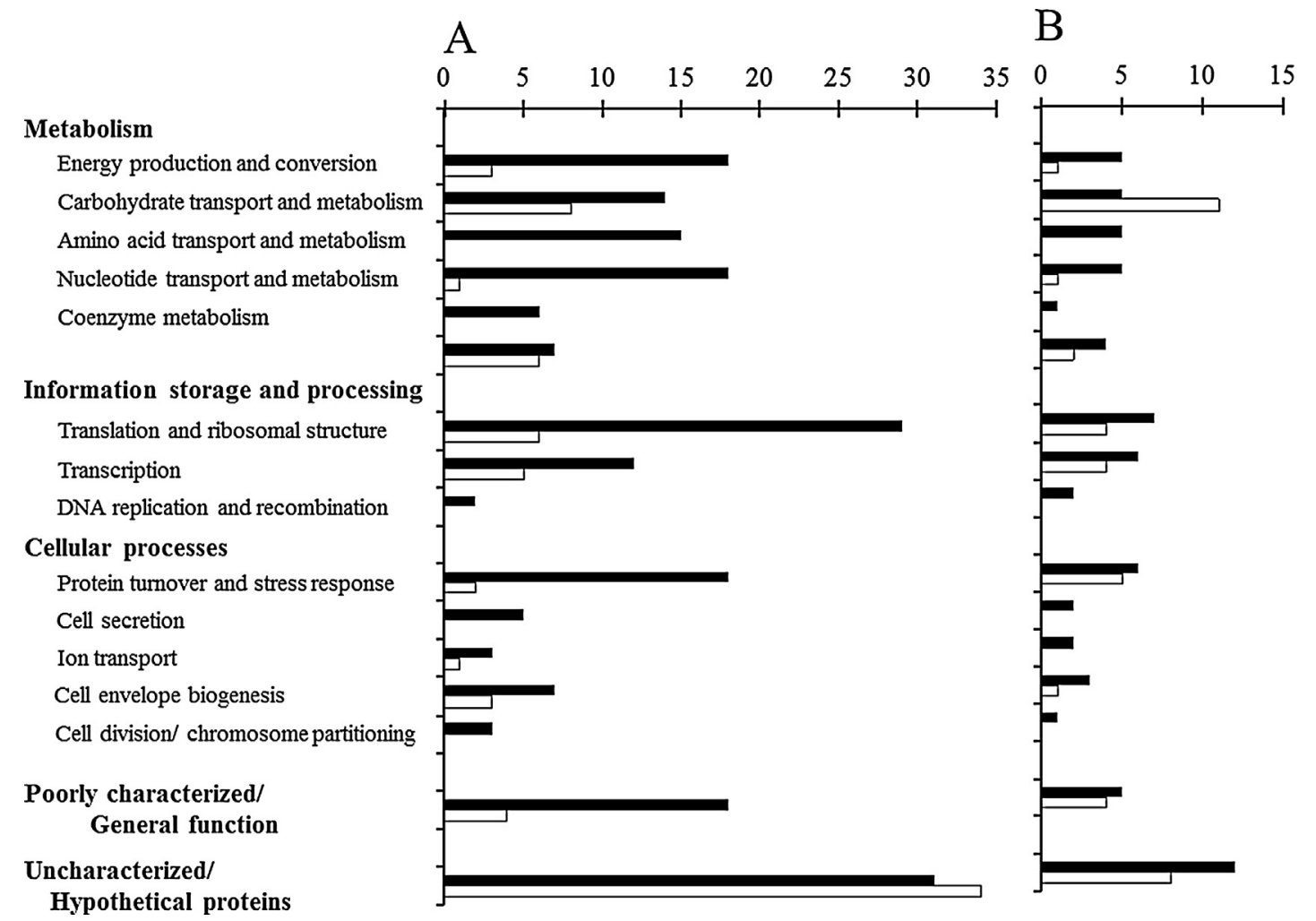

Fig 2. Numbers of B. longum NCC2705 genes, grouped according to functional category, that were significantly upregulated (black bars) or downregulated (white bars) after $1.25 \mathrm{mM} \mathrm{H}_{2} \mathrm{O}_{2}$ exposure for $5 \mathrm{~min}$ (panel A) or $60 \mathrm{~min}$ (panel B). 
Table 2

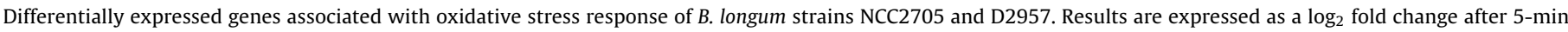
(T1) and 60-min (T2) compared to control (untreated) cells.

\begin{tabular}{|c|c|c|c|c|c|}
\hline \multirow[t]{2}{*}{ Gene ID } & \multirow[t]{2}{*}{ Predicted function } & \multicolumn{2}{|c|}{ NCC2705 } & \multicolumn{2}{|c|}{ D2957 } \\
\hline & & $\mathrm{T} 1$ & $\mathrm{~T} 2$ & $\mathrm{~T} 1$ & $\mathrm{~T} 2$ \\
\hline BL0555 & Trypsin-like serine proteases, typically periplasmic & 1.68 & n.s. & n.s. & n.s. \\
\hline BL0781 & Putative intracellular protease/amidase & 0.94 & 0.96 & n.s. & n.s. \\
\hline BL0944 & ATP-dependent endopeptidase clp proteolytic subunit clpP & n.s. & n.s. & n.s. & 0.96 \\
\hline BL0945 & Protease subunit of ATP-dependent Clp proteases & 0.79 & n.s. & n.s. & 1.48 \\
\hline BL1682 & ATP-dependent $\mathrm{Zn}$ proteases & 0.99 & n.s. & n.s. & n.s. \\
\hline BL0139 & NAD $(\mathrm{P}) \mathrm{H}$-dependent FMN reductase & n.s. & n.s. & n.s. & 1.92 \\
\hline BL0399 & Protoporphyrinogen oxidase & 1.06 & n.s. & n.s. & n.s. \\
\hline BL0552 & NADPH-dependent glutamate synthase beta chain and related oxidoreductases & n.s. & 1.03 & n.s. & n.s. \\
\hline BL0614 & Thioredoxin reductase & 1.92 & 1.56 & n.s. & 0.88 \\
\hline BL0615 & Peroxiredoxin & 1.36 & 1.29 & n.s. & 1.16 \\
\hline BL0668 & Glutaredoxin and related proteins & 1.79 & 1.59 & 1.57 & 1.49 \\
\hline BL0669 & NrdI protein/ribonucleotide reductase stimulatory protein & 1.42 & n.s. & n.s. & n.s. \\
\hline BL0670 & Ribonucleotide reductase, alpha subunit & 0.92 & n.s. & n.s. & n.s. \\
\hline BL0671 & Ribonucleoside-diphosphate reductase beta chain & 1.40 & n.s. & n.s. & 0.73 \\
\hline BL1563 & Ferredoxin & 0.86 & n.s. & n.s. & n.s. \\
\hline BL1750 & Exodeoxyribonuclease VII small subunit & 0.75 & 1.10 & n.s. & n.s. \\
\hline BL1752 & Oxygen-sensitive ribonucleoside-triphosphate reductase & 1.88 & 1.59 & n.s. & n.s. \\
\hline BL1753 & Anaerobic ribonucleoside-triphosphate reductase activating protein & 0.95 & 0.89 & n.s. & n.s. \\
\hline BLD_0988 & Thioredoxin & n.s. & n.s. & n.s. & 1.52 \\
\hline BL0001 & Cold shock proteins & 0.75 & n.s. & n.s. & 0.85 \\
\hline BL0002 & $60 \mathrm{kDa}$ chaperonin GROEL & n.s. & n.s. & n.s. & 1.09 \\
\hline BL0010 & ATPases with chaperone activity, ATP-binding subunit & 0.89 & n.s. & n.s. & n.s. \\
\hline BL0355 & Predicted nuclease of the RecB family & -0.82 & n.s. & n.s. & n.s. \\
\hline BL0517 & Molecular chaperone (small heat shock protein) & n.s. & 0.92 & n.s. & n.s. \\
\hline BL0519 & ATPases with chaperone activity, ATP-binding subunit & n.s. & -1.08 & n.s. & n.s. \\
\hline BL0520 & DnaJ-class molecular chaperone & n.s. & -1.28 & n.s. & n.s. \\
\hline BL1250 & Molecular chaperone & n.s. & -1.72 & n.s. & n.s. \\
\hline BL1558 & $10 \mathrm{kDa}$ chaperonin GROES & n.s. & n.s. & n.s. & 0.98 \\
\hline BLD_0001 & Cold shock protein & n.s. & n.s. & 1.51 & 1.06 \\
\hline BL1664 & Universal stress protein UspA and related nucleotide-binding proteins & -1.15 & -1.74 & n.s. & n.s. \\
\hline BLD_1771 & Stress-responsive transcriptional regulator PspC & 0.84 & n.s. & n.s. & n.s. \\
\hline
\end{tabular}

n.s.: Not significant.

\subsection{Microarray validation by $R T-P C R$}

To validate the microarray data, quantitative real-time PCR (RTPRC) was performed as described by Smeianov et al. (2007) for 6 different genes (Table 1 ) using cDNA produced after each treatment. A log-fold change (LFC) was calculated between control and treatment samples, and graphed vs. the LFC calculated from the microarray data.

\subsection{Microarray data accession number}

Microarray hybridization data have been deposited in the Gene Expression Omnibus under accession number GSE44709.

\subsection{Whole genome sequencing of B. longum D2957}

Total genomic DNA was isolated from strain D2957 using the Masterpure Gram Positive DNA purification kit (Epicenter Biotechnologies, Madison WI) then high-throughput whole-genome shotgun DNA sequencing and assembly was performed at the Utah State University Center for Integrated Biosystems using the Roche 454 GS Titanium pyrosequencer platform. The sequence data was assembled into a $2.33 \mathrm{Mbp}$ draft genome consisting of 13 contigs, and automated genome annotation was performed using the RAST algorithm (rast.nmpdr.org).

The whole genome shotgun sequence for B. longum D2957 has been deposited at DDBJ/EMBL/GenBank under the accession AQGL00000000. The version described in this paper is the first version, AQGL01000000.

\subsection{Membrane fatty acid analysis}

To determine whether $\mathrm{H}_{2} \mathrm{O}_{2}$ exposure altered cytoplasmic membrane fatty acid (CMFA) composition, cells were grown in batch culture as described, and treated with a sublethal $\mathrm{H}_{2} \mathrm{O}_{2}$ concentration of $1.25 \mathrm{mM}$ for 5 (T1) or 60 (T2) min. Twenty mL samples were collected by centrifugation at $5000 \times g$ for $5 \mathrm{~min}$ and then washed twice with phosphate buffered saline. Membrane fatty acids were isolated from the pelleted cells according to the protocol of Sasser (1990) and identified using gas chromatography as described previously (Oberg et al., 2012). An untreated control sample was also prepared. Amounts of individual fatty acids were calculated as a percent of total and a two-tailed student t-test was used to determine differences in means between samples.

\section{Results and discussion}

\subsection{Influence of $\mathrm{H}_{2} \mathrm{O}_{2}$ stress on global gene expression}

To explore possible causes for differences in $\mathrm{H}_{2} \mathrm{O}_{2}$ resistance between $B$. longum NCC2705 and D2957, we analyzed their transcriptional changes after 5- or 60 -min sublethal $\mathrm{H}_{2} \mathrm{O}_{2}$ exposure. Because our original DNA microarray design was based on the two B. longum genomes (NCC2705 and DJO10A) that were publicly available at the time, whole genome pyrosequencing of $B$. longum D2957 was first performed to better interpret the transcriptome results for this strain and to identify genes that were unlikely to hybridize to the microarray. Prior data from whole genome hybridizations with Bifidobacterium strains against the custom microarray (unpublished data) was used to estimate the cutoff threshold for hybridization of D2957 genes to the array. Those results suggested D2957 genes encoding proteins with $\leq 77 \%$ 

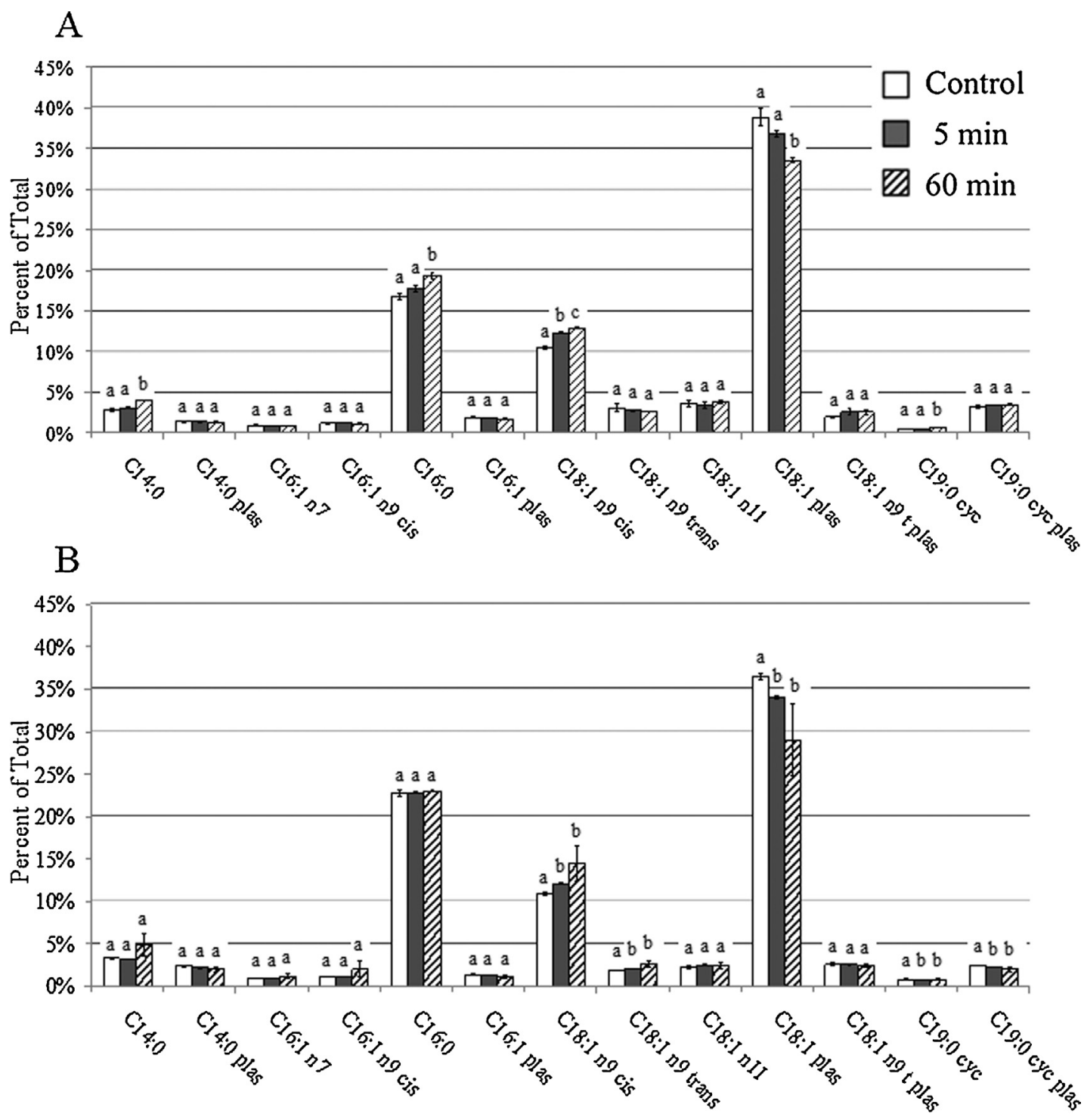

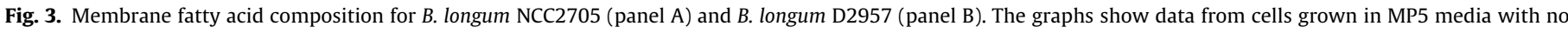

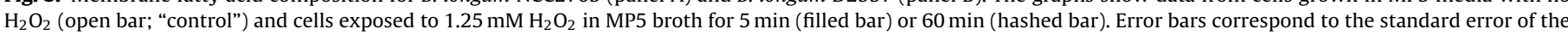
mean (SEM). Means with the same letters within each strain are not statistically significantly different $(p$-value $<0.05)$.

amino acid identity to array targets were unlikely to hybridize, and therefore deemed not detectable. Among the 2073 predicted open reading frames in the D2957 genome, 495 were below the cutoff value (see Supplementary material Table S1). The 350 (71\%) of these genes encoded hypothetical proteins or had only general function.

Among the 1578 B. longum D2957 genes that were represented on the array, 21 showed statistically significant $(P<0.05)$ DE genes compared to control cells after 5 min exposure to a sublethal $\mathrm{H}_{2} \mathrm{O}_{2}$ exposure, and 90 differentially expressed (DE) genes were detected after 60 min exposure. Of these, $12(60 \%)$ and 65 (76\%) of the genes that were DE after 5 and 60 min, respectively, have an assigned function (Fig. 1 and Table S2). In contrast, B. longum NCC2705 showed a total of 288 significantly $(P<0.05)$ DE genes after a 5 min exposure, and $114 \mathrm{DE}$ genes after 60 min (Fig. 1). Among the DE genes detected after 5 or $60 \mathrm{~min}, 192(69 \%)$ and $83(74 \%)$, respectively, have an assigned function (Fig. 2 and Table S2 in the Supplemental material).

RT-PCR analysis of 6 selected genes was used to validate microarray data obtained from B. longum NCC2705 and D2957. RT-PCR did not detect any contradictions between the two platforms (Fig. S1), and there was a positive correlation $\left(r^{2}=0.68\right.$ and
0.63 , respectively) between the fold-change for gene induction or repression predicted from the microarray and the respective values determined by RT-PCR.

Due to their anaerobic nature, Bifidobacterium ssp. lack the most common enzymes associated with oxidative stress defense, such as super oxide dismutase and catalase. However, other anaerobic bacteria have developed different systems to mitigate the toxic effects of $\mathrm{H}_{2} \mathrm{O}_{2}$ such as NADH peroxidases, peroxiredoxin, ferritinelike iron binding proteins and DNA repair enzymes (Yamamoto et al., 2011; Brioukhanov and Netrusov, 2007). Initial grouping of DE genes into predicted functional categories showed $\mathrm{H}_{2} \mathrm{O}_{2}$ exposure triggered up-regulation of genes involved in several such systems in both strains (Table 2). Examples include several genes involved in the thioredoxin reductase system which, under favorable growth conditions, functions with ribonucleoside reductase to use NADPH to reduce the $2^{\prime} \mathrm{OH}$ group of ribose for deoxynucleotide production, as well as to maintain cytoplasmic redox for disulfide bond production in proteins (Nordlund and Reichard, 2006; Arnér and Holmgren, 2001). During oxidative stress; however, cells may use thioredoxin reductase and peroxiredoxin to direct NADPH toward the removal of oxidative free radicals via the reduction 
of $\mathrm{H}_{2} \mathrm{O}_{2}$ and toxic lipid hydroperoxides (Reott et al., 2009; Meyer et al., 2009; Holmgren, 1989). Schell et al. (2002) suggested these enzymes might be one of the primary defense mechanisms against oxidative stress in bifidobacteria, and other research has shown upregulation of thioredoxin, thioredoxin reductase and peroxiredoxin in response to oxygen stress (Ruiz et al., 2012; Xiao et al., 2011). B. longum NCC2705 showed significant up regulation of thioredoxin reductase (BL0614) and peroxiredoxin (BL0615) along with ribonucleotide reductase alpha and beta subunits (BL0670 and BL0671) after only 5 min sublethal $\mathrm{H}_{2} \mathrm{O}_{2}$ treatment (Table 2). In contrast, D2957 did not display significant upregulation of these genes until 60 min exposure to $\mathrm{H}_{2} \mathrm{O}_{2}$. These results confirm that thioredoxin reductase and peroxiredoxin provide a primary defense mechanism against oxidative stress in $B$. longum and suggest that the greater $\mathrm{H}_{2} \mathrm{O}_{2}$ resistance of strain NCC2705 versus D2957 may be tied to earlier induction of these mechanisms.

Oxidative stress causes protein damage and denaturation, and protection of proteins and processing of damaged proteins is an important component of the oxidative stress response in bacteria (Shacter, 2000; Stadtman and Levine, 2000; Cabiscol et al., 2000). Although, bifidobacteria possess well studied chaperones and chaperonins (e.g., DnaJ/DnaK and GroEL/GroES), their role in $\mathrm{H}_{2} \mathrm{O}_{2}$ resistance is unclear. B. longum NCC2705 for example, showed significant down regulation of several general stress response genes, including DnaJ, UspA and several chaperone proteins (BL0519, BL1250 and BL1664) in response to $\mathrm{H}_{2} \mathrm{O}_{2}$ exposure (Table 2). This observation is consistent with prior studies, which reported no change in expression or down regulation of the general stress response genes in response to acid stress (Jin et al., 2012; Sanchez et al., 2007). However, NCC2705 did show an up regulation of several proteases (BL0555, BL0781 and BL0945) after 5 min $\mathrm{H}_{2} \mathrm{O}_{2}$ exposure, including an ATP-dependent metallo-protease (BL1682). Jin et al. (2012) also reported upregulation of a similar metalloprotease during acid stress, which was hypothesized to function in response to damage of membrane proteins which result in perturbation of membrane function (Sakoh et al., 2005). In contrast, strain D2957 only showed upregulation of two proteases (BL0944 and BL0945) after 60 min exposure.

\subsection{Membrane fatty acid analysis}

Prior research we conducted on the oxidative stress responses of $B$. animalis subsp. lactis showed that two nearly genetically identical strains had statistically significant differences in bacterial cell membrane fatty acid composition (CMFA), and that these differences greatly affected the intrinsic resistance of those strains to $\mathrm{H}_{2} \mathrm{O}_{2}$ exposure (Oberg et al., 2012). These observations are consistent with other research that has shown changes in CMFA composition during stress exposure, and that modification of CMFA composition can increase cell resistance to environmental (Vigh et al., 2005; Zhang and Rock, 2008; Baysse and O'Gara, 2007; van Bokhorst-van de Veen et al., 2011; Cotter and Hill, 2003). Because of the prior observations in Bifidobacterium, the CMFA composition of B. longum strains NCC2705 and D2957 was determined after $5 \mathrm{~min}$ (T1) or $60 \mathrm{~min}$ (T2) $1.25 \mathrm{mM} \mathrm{H}_{2} \mathrm{O}_{2}$ exposure. Results showed that overall, NCC2705 had a significant increase in both C16:0 and C18:1 n9, but a decrease in the C18:1 plasmalogen when compared to cells grown in control media (Fig. 3). Strain D2957 showed a similar increase in C18:1 $\mathrm{n} 9$ and a decrease in C18:1 plasmalogen after exposure to $2.55 \mathrm{mM} \mathrm{H}_{2} \mathrm{O}_{2}$, but no change in $\mathrm{C} 16: 0$ (Fig. 3).

Direct comparison between the two strains showed they maintain a similar membrane composition, with a very low saturated to unsaturated fatty acid ratio and that the majority of the unsaturated fatty acids occur as C18:1 plasmalogens (Oberg et al., 2012). These vinyl ether-linked lipids are more easily oxidized at the carbon oxygen ether bond, and do not propagate free radicals when oxidized compared to their ester linked counterparts (Catalá, 2009; Magnusson and Haraldsson, 2011). Interestingly both strains had low amounts of cyclopropyl fatty acids, which are suggested to decrease the amount of lipid peroxidation in cell membranes by stabilizing the unsaturated bond by addition of a methyl group (Pradenas et al., 2012).

\section{Conclusions}

In summary, transcriptome data suggest that the significant differences in the intrinsic and inducible resistance to $\mathrm{H}_{2} \mathrm{O}_{2}$ noted previously between B. longum NCC2705 and D2957 (Oberg et al., 2011) may be largely due to the timing and degree of induction of genes involved in an oxidative stress response. These data demonstrate that NCC2705 has a rapid and highly inducible $\mathrm{H}_{2} \mathrm{O}_{2}$ stress response, whereas strain $\mathrm{D} 2957$ showed a more delayed and less pronounced transcriptional response to $\mathrm{H}_{2} \mathrm{O}_{2}$ stress. Because of the highly reactive nature of oxidative free radicals, an immediate and robust inducible stress response may be more effective in neutralizing the damaging effects of $\mathrm{H}_{2} \mathrm{O}_{2}$.

Overall, these findings provide new insights to the molecular basis for oxidative stress resistance in B. longum and the factors that influence to strain-to-strain variability in survival in bioactive food products.

\section{Acknowledgments}

This project was supported by National Research Initiative Grant no. 2006-35503-17194 from the USDA Cooperative State Research, Education, and Extension Service Improving Food Quality and Value Program, and by the Utah Agricultural Experiment Station. This communication is approved as UAES Journal Paper Number 8604. Peggy Steele, a member of Dr. Steele's family, is employed by Dupont Inc., a supplier of bacterial cultures to the food industry.

\section{Appendix A. Supplementary data}

Supplementary data associated with this article can be found, in the online version, at http://dx.doi.org/10.1016/j.jbiotec.2015.06. 405.

\section{References}

Arnér, E.S.J., Holmgren, A., 2001. Physiological functions of thioredoxin and thioredoxin reductase. Eur. J. Biochem. 267, 6102-6109.

Barrangou, R., Briczinski, E.P., Traeger, L.L., Loquasto, J.R., Richards, M., Horvath, P., Couté-Monvoisin, A.-C., Leyer, G., Rendulic, S., Steele, J.L., Broadbent, J.R., Oberg, T., Dudley, E.G., Schuster, S., Romero, D.A., Roberts, R.F., 2009. Comparison of the complete genome sequences of Bifidobacterium animalis subsp. lactis DSM 10140 and Bl-04. J. Bacteriol. 191, 4144-4151.

Baysse, C., O'Gara, F.,2007. Role of membrane structure during stress signaling and adaptation in Pseudomonas. In: Ramos, J.-L., Filloux, A. (Eds.). Springer Science, Business Media, Inc., New York, NY, pp. 193-224

Bermudez-Brito, M.M., Plaza-Díaz, J.J., Muñoz-Quezada, S.S., Gómez-Llorente, C.C., Gil, A.A., 2012. Probiotic mechanisms of action. Ann. Nutr. Metab. 61, 160-174.

Brioukhanov, A., Netrusov, A., 2007. Aerotolerance of strictly anaerobic microorganisms and factors of defense against oxidative stress: a review. Appl. Biochem. Microbiol. 43, 567-582.

Cabiscol, E., Tamarit, J., Ros, J., 2000. Oxidative stress in bacteria and protein damage by reactive oxygen species. Int. Microbiol. 3, 3-8.

Catalá, A., 2009. Lipid peroxidation of membrane phospholipids generates hydroxy-alkenals and oxidized phospholipids active in physiological and/or pathological conditions. Chem. Phys. Lipids 157 (1), 1-11.

Chen, C.-C., Kong, M.-S., Lai, M.-W., Chao, H.-C., Chang, K.-W., Chen, S.-Y., Huang, Y.-C., Chiu, C.-H., Li, W.-C., Lin, P.-Y., Chen, C.-J., Li, T.-Y., 2010. Probiotics have clinical, microbiologic, and immunologic efficacy in acute infectious diarrhea. Pediatr. Infect. Dis. J. 29, 135-138.

Cotter, P.D., Hill, C., 2003. Surviving the acid test: responses of Gram-positive bacteria to low pH. Microbiol. Mol. Biol. Rev. 67, 429-453.

Dong, P., Yang, Y., Wang, W.-P., 2010. The role of intestinal bifidobacteria on immune system development in young rats. Early Hum. Dev. 86, 51-58. 
Fontana, L., Bermudez-Brito, M., Plaza-Diaz, J., Muñoz-Quezada, S., Gil, A., 2013. Sources, isolation, characterization and evaluation of probiotics. BJN 109, S35-S50.

Holmgren, A., 1989. Thioredoxin and glutaredoxin systems. J. Biol. Chem. 264, 13963-13966

Jin, J., Zhang, B., Guo, H., Cui, J., Jiang, L., Song, S., Sun, M., Ren, F., 2012. Mechanism analysis of acid tolerance response of Bifidobacterium longum subsp. longum BBMN 68 by gene expression profile using RNA-sequencing. PLoS One 7 , e50777

Klaassens, E.S., Boesten, R.J., Haarman, M., Knol, J., Schuren, F.H., Vaughan, E.E., De Vos, W.M., 2009. Mixed-species genomic microarray analysis of fecal samples reveals differential transcriptional responses of bifidobacteria in breast- and formula-fed infants. Appl. Environ. Microbiol. 75, 2668-2676.

Magnusson, C.D., Haraldsson, G.G., 2011. Ether lipids. Chem. Phys. Lipids 164, 315-340.

Makinen, K., Berger, B., Bel-Rhlid, R., Ananta, E., 2012. Science and technology for the mastership of probiotic applications in food products. J. Biotechnol. 162 356-365.

Meance, S., Cayuela, C., Turchet, P., Raimondi, A., Lucas, C., Antoine, J.-M., 2001. A fermented milk with a Bifidobacterium probiotic strain DN-173 010 shortened oro-fecal gut transit time in elderly. Microbiol. Ecol. Health Dis. 13, 217-222.

Meyer, Y., Buchanan, B.B., Vignols, F., Reichheld, J.-P., 2009. Thioredoxins and glutaredoxins: unifying elements in redox biology. Annu. Rev. Genet. 43, 335-367.

Nordlund, P., Reichard, P., 2006. Ribonucleotide reductases. Annu. Rev. Biochem. $75,681-706$

Oberg, T.S., Steele, J.L., Ingham, S.C., Smeianov, V.V., Briczinski, E.P., Abdalla, A., Broadbent, J.R., 2011. Intrinsic and inducible resistance to hydrogen peroxide in Bifidobacterium species. J. Ind. Microbiol. Biotechnol. 38, 1947-1953.

Oberg, T.S., Ward, R.E., Steele, J.L., Broadbent, J.R., 2012. Identification of plasmalogens in the cytoplasmic membrane of Bifidobacterium animalis subsp. lactis. Appl. Environ. Microbiol. 78, 880-884.

Oberg, T.S., Ward, R.E., Steele, J.L., Broadbent, J.R., 2013. Genetic and physiological responses of Bifidobacterium animalis subsp. lactis to hydrogen peroxide stress, J. Bacteriol. 195, 3743-3751.

Pradenas, G.A., Paillavil, B.A., Reyes-Cerpa, S., Pérez, J.M., Vásquez, C.C., 2012. Reduction of the monounsaturated fatty acid content of Escherichia coli K-12 results in increased resistance to oxidative damage. Microbiology 158, 1279-1283.

Reid, G., Beuerman, D., Heinemann, C., Bruce, A.W., 2001. Probiotic Lactobacillus dose required to restore and maintain a normal vaginal flora. FEMS Immunol. Med. Microbiol. 32, 37-41.

Reott, M.A., Parker, A.C., Rocha, E.R., Smith, C.J., 2009. Thioredoxins in redox maintenance and survival during oxidative stress of Bacteroides fragilis. J. Bacteriol. 191, 3384-3391.

Ruiz, L., Ruas- Madiedo, P., Gueimonde, M., los, R., eyes-Gavilan, C.G., Margolles, A., Sánchez, B., 2011. How do bifidobacteria counteract environmental challenges? Mechanisms involved and physiological consequences. Genes Nutr. 6, 307-318.

Ruiz, L., Gueimonde, M., Ruas- Madiedo, P., Ribbera, A., De, L., os, R., eyes-Gavilan, C.G., Ventura, M., Margolles, A., Sanchez, B., 2012. Molecular clues to understand the aerotolerance phenotype of Bifidobacterium animalis subsp. lactis. Appl. Environ. Microbiol. 78, 644-650.

Sakoh, M., Ito, K., Akiyama, Y., 2005. Proteolytic activity of HtpX, a membrane-bound and stress-controlled protease from Escherichia coli. J. Biol. Chem. 280, 33305-33310

Sanchez, B., Champomier-Verges, M.-C., Collado, M.D.C., Anglade, P., Baraige, F. Sanz, Y., De Los Reyes-Gavilan, C.G., Margolles, A., Zagorec, M., 2007. Low-pH adaptation and the acid tolerance response of Bifidobacterium longum biotype longum. Appl. Environ. Microbiol. 73, 6450-6459.

Sasser, M., 1990. Identification of Bacteria by Gas Chromatography of Cellular Fatty Acids. Technical Note 101. Midi, Inc., Newark, DE http://www.microbialid.com/ PDF/TechNote_101.pdf

Schell, M.A., Karmirantzou, M., Snel, B., Vilanova, D., Berger, B., Pessi, G., Zwahlen M.-C., Desiere, F., Bork, P., Delley, M., Pridmore, R.D., Arigoni, F., 2002. The genome sequence of Bifidobacterium longum reflects its adaptation to the human gastrointestinal tract. Proc. Natl. Acad. Sci. U. S. A. 99, 14422-14427.

Scholtens, D., von Heydebreck, A., 2005. Analysis of differential gene expression studies. In: Gentleman, R., Carey, V., Huber, W., Irizarry, R., Dudoit, S. (Eds.), Bioinformatics and Computational Biology Solutions Using R and Bioconductor Springer Science, Business Media, Inc., New York, NY, pp. 229-248.

Shacter, E., 2000. Quantification and significance of protein oxidation in biological samples. Drug Metab. Rev. 32, 307-326.

Smeianov, V.V., Wechter, P., Broadbent, J.R., Hughes, J.E., Rodriguez, B.T., Christensen, T.K., Ardo, Y., Steele, J.L., 2007. Comparative high-density microarray analysis of gene expression during growth of Lactobacillus helveticus in milk versus rich culture medium. Appl. Environ. Microbiol. 73, 2661-2672

Stadtman, E.R., Levine, R.L., 2000. Protein oxidation. Ann. N. Y. Acad. Sci. 899 $191-208$

Stanton, C.C., Gardiner, G.G., Meehan, H.H., Collins, K.K., Fitzgerald, G.G., Lynch, P.B., Ross, R.P., 2001. Market potential for probiotics. Am. J. Clin. Nutr. 73, 476S-483S.

Stevens, J.R., Ganesan, B., Desai, P., Rajan, S., Weimer, B.C., 2008. Statistical issues in the normalization of multi-species microarray data. Proc. Conf. App. Stats. Agric. Kansas State University, 47-62.

van Bokhorst-van de Veen, H., Abee, T., Tempelaars, M., Bron, P.A., Kleerebezem, M., Marco, M.L., 2011. Short- and long-term adaptation to ethanol stress and its cross-protective consequences in Lactobacillus plantarum. Appl. Environ. Microbiol. 77, 5247-5256.

Vaughan, E., Heilig, H., Benamor, K., Devos, W., 2005. Diversity, vitality and activities of intestinal lactic acid bacteria and bifidobacteria assessed by molecular approaches. FEMS Microbiol. Rev. 29, 477-490.

Vigh, L., Escribá, P., Sonnleitner, A., Sonnleitner, M., Piotto, S., Maresca, B., Horváth I., Harwood, J., 2005. The significance of lipid composition for membrane activity: new concepts and ways of assessing function. Prog. Lipid Res. 44, 303-344.

Vries, W., Stouthamer, A.H., 1969. Factors determining the degree of anaerobiosis of Bifidobacterium strains. Arch. Microbiol. 65, 275-287.

Waller, P.A., Gopal, P.K., Leyer, G.J., Ouwehand, A.C., Reifer, C., Stewart, M.E., Miller L.E., 2011. Dose-response effect of Bifidobacterium lactis HN019 on whole gut transit time and functional gastrointestinal symptoms in adults. Scand. J. Gastroenterol. 46, 1057-1064.

Xiao, M., Xu, P., Zhao, J., Wang, Z., Zuo, F., Zhang, J., Ren, F., Li, P., Chen, S., Ma, H., 2011. Oxidative stress-related responses of Bifidobacterium longum subsp. longum BBMN68 at the proteomic level after exposure to oxygen. Microbiology 157, 1573-1588.

Yamamoto, Y., Gaudu, P., Gruss, A., 2011. Oxidative stress and oxygen metabolism in lactic acid bacteria. In: Sonomoto, K., Yokota, A. (Eds.), Lactic Acid Bacteria and Bifidobacteria: Current Progress in Advanced Research. Caister Academic Press, Norfolk, England, pp. 91-102.

Zhang, L.-L., Chen, X., Zheng, P.-Y., Luo, Y., Lu, G.-F., Liu, Z.-Q., Huang, H., Yang, P.-C. 2009. Oral Bifidobacterium modulates intestinal immune inflammation in mice with food allergy. J. Gastroenterol. Hepatol. 25, 928-934.

Zhang, Y.-M., Rock, C.O., 2008. Membrane lipid homeostasis in bacteria. Nat. Rev. Microbiol. 6, 222-233. 